This article was downloaded by: [University of Manchester]

On: 30 September 2009

Access details: Access Details: [subscription number 908308356]

Publisher Routledge

Informa Ltd Registered in England and Wales Registered Number: 1072954 Registered office: Mortimer House, 37-41 Mortimer Street, London W1T 3JH, UK

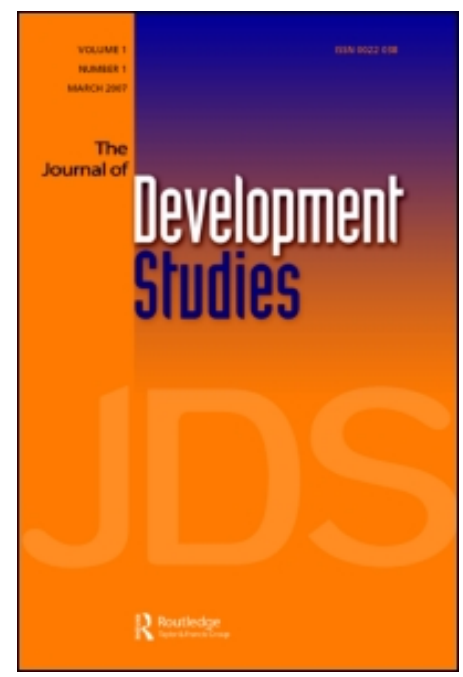

Journal of Development Studies

Publication details, including instructions for authors and subscription information:

http://www.informaworld.com/smpp/title content=t713395137

\title{
State Business Relations and Economic Growth in Sub-Saharan Africa
}

Kunal Sen a; Dirk Willem Te Velde ${ }^{\mathrm{b}}$

a University of Manchester, Manchester, UK ${ }^{\text {b }}$ Overseas Development Institute, London, UK

Online Publication Date: 01 September 2009

To cite this Article Sen, Kunal and Te Velde, Dirk Willem(2009)'State Business Relations and Economic Growth in Sub-Saharan

Africa',Journal of Development Studies,45:8,1267 - 1283

To link to this Article: DOI: $10.1080 / 00220380902863307$

URL: http://dx.doi.org/10.1080/00220380902863307

\section{PLEASE SCROLL DOWN FOR ARTICLE}

\footnotetext{
Full terms and conditions of use: http://www.informaworld.com/terms-and-conditions-of-access.pdf

This article may be used for research, teaching and private study purposes. Any substantial or systematic reproduction, re-distribution, re-selling, loan or sub-licensing, systematic supply or distribution in any form to anyone is expressly forbidden.

The publisher does not give any warranty express or implied or make any representation that the contents will be complete or accurate or up to date. The accuracy of any instructions, formulae and drug doses should be independently verified with primary sources. The publisher shall not be liable for any loss, actions, claims, proceedings, demand or costs or damages whatsoever or howsoever caused arising directly or indirectly in connection with or arising out of the use of this material.
} 


\title{
State Business Relations and Economic Growth in Sub-Saharan Africa
}

\author{
KUNAL SEN* \& DIRK WILLEM TE VELDE** \\ *University of Manchester, Manchester, UK, **Overseas Development Institute, London, UK
}

Final version received September 2008

\begin{abstract}
This paper contributes to the literature on the determinants of economic growth in sub-Saharan Africa by examining the effect of effective state-business relations on economic growth for a panel of 19 sub-Saharan African countries for the period 1970-2004. We propose a measure that we argue captures the various dimensions of effective state-business relations in subSaharan Africa. We then estimate standard growth regressions using dynamic panel data methods with this measure, along with the more conventionally used measures of institutional quality such as degree of executive constraints, the rule of law, the degree of corruption and the quality of the bureaucracy. Our results show that effective state-business relations contribute significantly to economic growth - countries which have shown improvements in state-business relations have witnessed higher economic growth, controlling for other determinants of economic growth and independent of other measures of institutional quality.
\end{abstract}

\section{Introduction}

There is by now an extensive literature that has studied why African countries have grown so slowly, examining the various determinants of economic growth in subSaharan African countries. This literature finds that distorted product and credit

Correspondence Address: Kunal Sen, University of Manchester, Manchester, UK.

Email: kunal.sen@manchester.ac.uk

This is a revised version of Improving Institutions for Pro-Poor Growth (IPPG) Discussion Paper No. 8 available at www.ippg.org.uk/publications.html. The research was undertaken for the IPPG Research Programme Consortium, funded by the Department For International Development (DFID), UK. The authors are grateful to DFID for the funding that made this research possible. The views expressed in this paper are entirely those of the authors and in no way represent either the official policy of DFID or the policy of any other part of the UK Government. Different versions of this paper has been presented in the ABCDE Conference of the World Bank, the Africa Task Force of the Institute for Policy Dialogue and the Brooks World Poverty Institute, the annual conference of the Centre for Development Studies, University of Glasgow, and in a seminar at the Reading University Business School. Comments from participants and from members of the IPPG Consortium are gratefully acknowledged. The usual disclaimer applies.

An Online Appendix is available for this article which can be accessed via the online version of this journal available at www.informaworld.com/fjds 
markets, high risk in economic transactions, high rates of public expenditure, macroeconomic instability, lack of openness to trade, and inadequate infrastructure along with high ethnic fragmentation, adverse geographical conditions and high incidence of civil wars are important factors in explaining why African countries have tended to grow slowly, especially since the 1980s (Sachs and Warner, 1997; Easterly and Levine, 1997; Collier and Gunning, 1999; Artadi and Sala-i-Martin, 2003; Gyimah-Brempong and Corley, 2005). One important strand of this literature has focused on governance and institutions - in particular, the risk of expropriation (Hall and Jones, 1999; Acemoglu et al., 2001; Rodrik et al., 2004; Mauro, 1995) and the high degree of corruption - as being an important 'deep determinant' of economic growth in sub-Saharan African countries. In this paper, we examine a specific set of institutions - the formal institutional relations between states and the business sector - as a possible cause of variations in economic growth among subSaharan African countries, both across countries and over time.

Our motivation for focusing on state-business relations as an additional determinant of economic growth is influenced by a longstanding literature in political science and political economy that collaborative state-business relations (SBRs) can be growth-enhancing (for example, Amsden, 1989; Evans, 1995). This literature has argued that sustained economic growth has occurred in contexts where the state has intervened in the economy so as 'to provide incentives to private capital and to discipline it' (Harriss, 2006) and takes the position that 'good growthenhancing relations between business and government elites are possible' (Maxfield and Schneider, 1997). The empirical evidence in support of this view has been mostly from case studies, predominantly drawn from East Asia (for example Johnson, 1987) or Latin America (Doner and Schneider, 2000). Some recent firm-level studies provide evidence that state support contributes to firm survival and growth (Fajnzylber et al., 2009; Hansen et al., 2009). ${ }^{1}$ There is as yet limited knowledge of whether effective state-business relations in sub-Saharan Africa can contribute to economic growth. This is an important omission in the literature, given that in the political science literature on Africa there has been recognition of growth-impeding collusive behaviour among weak and fragmented political and economic elites that has characterised most African countries, along with examples of political elites that formed successful 'growth coalitions' with economic elites in countries as disparate in initial conditions and geographical characteristics as Botswana, Ghana and Mauritius (Herbst, 1993; Bräutigam et al., 2002; Robinson and Parsons, 2006). ${ }^{2}$

In this paper, we contribute to the literature on the determinants of economic growth in sub-Saharan Africa by focusing our attention on a relatively underemphasised aspect of economic growth - the importance of effective statebusiness relations. ${ }^{3}$ We first situate the state-business relations in the literature on economic growth and discuss a measure of state-business relations for 19 subSaharan African countries over the period 1970-2004. ${ }^{4}$ We then use this measure along with other measure of institutional quality such as the rule of law, the degree of corruption and the degree of constraints on the executive that have been found to be important determinants of economic growth in the sub-Saharan Africa (SSA) context, in empirical growth regressions. We show that effective state business relations as captured by our measure have an unambiguous positive 
effect on economic growth and that this finding is robust to alternative estimation methods and specifications.

The remainder of the paper is organised as follows. Firstly, in Section II, we discuss the theoretical basis of why effective state-business relations matters for economic growth. In Section III, we describe our measure of effective state-business relations and provide estimates of it for a set of 19 SSA countries where we have the necessary data for the period 1970-2004. In Section IV, we discuss our empirical specification, the data used in the regressions and the econometric methodology. Section V presents the results. Section VI concludes.

\section{Why Do Effective State-Business Relations Matter for Economic Growth?}

The literature on state-business relations takes the following elements as essential characteristics of effective state-business relations (see Maxfield and Schneider, 1997: Chapter 1).

- Transparency: the flow of accurate and reliable information, both ways, between business and government.

- Reciprocity: the capacity and autonomy of state actions to secure improved performance in return for subsidies.

- Credibility: when capitalists are able to believe what state actors say.

Effective SBRs as characterised above can affect growth through fulfilling a number of economic functions. Firstly, they can help to solve information related market and co-ordination failures in areas such as skill development or infrastructure provision. For instance, business associations or government departments may coordinate and disperse information among stakeholders.

Secondly, effective SBRs provide a check and balance function on government policies and tax and expenditure plans. Thus, effective SBRs may help to ensure that the provision of infrastructure is appropriate and of good quality. The design of effective government policies and regulations depends, among other things, on input from and consultation with the private sector. Regular sharing of information between the state and businesses ensures that private sector objectives are met with public action and that local level issues are fed into higher level policy processes. The private sector can identify constraints, opportunities, and possible policy options for creating incentives, lowering investment risks, and reducing the cost of doing business. More efficient institutions and rules and regulations might be achieved through policy advocacy which could reduce the costs and risks faced by firms and enhance productivity.

Finally, effective state-business relations and membership of business associations may help to reduce policy uncertainty. Firms operate in an uncertain environment and frequently face risk and resource shortages. They undertake decisions concerning technology, inputs, and production facilities based on anticipated market conditions and profitability. Uncertainty can have significant negative effects on investment, when investment involves large sunk and irreversible costs and there is the option to delay the decision to make the investment until further information becomes available (Dixit and Pindyck, 1994). Businesses that have a better relation with government may be able to anticipate policy decisions. 
Hisahiro (2005) argues that various forms of information and resources, which are dispersed among entities in the public and private sector, need to be integrated in a more sophisticated way to jointly coordinate policies and provide better public services. It is this combination of insulation and connectedness that minimises the risks and enhances the effectiveness of economic policies. Hence, appropriate government capacity and policy, which is necessary to support private sector development and promote economic growth, can be enabled by good state-business relations and productive public-private sector dialogue.

Thus, effective state-business relations can enhance economic growth by positively affecting the two proximate determinants of growth - the rate of factor accumulation and the growth of total factor productivity. Greater transparency in the flow of information between state actors and the business sector leads both to a better allocation of investments by the business sector to their most productive uses and, by reducing policy uncertainty in the minds of investors, a higher rate of investment. Higher credibility of state actions lead to less problems of time and dynamic inconsistency of government policies, providing a more favourable environment for investment to occur. Reciprocity ensures improved performance by private sector actors in return for subsidies and the provision of public goods, contributing to higher productivity growth in the economy.

In summary, effective state-business relations can mitigate both market failures and government failures which are pervasive in most developing countries, and by doing so bring about an increase in economic growth.

\section{Measuring State-Business Relationships in Sub-Saharan Africa}

In-depth discussions of state-business relations have so far focused mostly on Asian countries such as Korea, Japan, Malaysia, Bangladesh and Thailand (for example Hisahiro, 2005) or Latin America (Doner and Schneider, 2000). The measurement of state-business relations is still in its infancy and nearly absent in SSA, despite its potential importance for economic development. ${ }^{5}$ Hyden et al. (2004) focus on six governance categories of which economic society is one, and this includes (deliberately) subjective questions covering perceptions of state-business relations. It covers several developing countries, but only two African countries. The Kaufmann et al. (2005) indicators have become frequently used, but are also about perceptions of governance variables such as government effectiveness and rule of law. Finally, while investment climate measures in the World Bank's Doing Business reports are objective (for example, number of procedures to obtain a licence), these are unlikely to be fundamental drivers of economic performance, and can rather be seen as outcomes of effective state-business relations. There is therefore a lack of description and comprehensive measurement of SBRs as potentially fundamental drivers of economic growth in SSA.

In order to measure SBRs and assess their importance for economic performance, we need to measure the essence of SBRs. Following the discussion in the previous section, we argue that there are four main elements responsible for good SBRs:

i) the way in which the private sector is organised vis-à-vis the public sector

ii) the way in which the government is organised vis-à-vis the private sector

iii) the practice and institutionalisation of SBRs

iv) the avoidance of harmful collusive behaviour. 
We construct a composite measure of SBRs based on the above four elements for 19 SSA countries for which we have data for the period 1970-2004. Our measure is similar in principle to those used to measure the restrictiveness of trade policy, in that we are trying to capture the institutional relations between states and businesses that may lead to better outcomes for investment and growth, rather than the outcomes themselves. ${ }^{6}$ Thus, we are interested in the 'causes' of better investment climate outcomes rather than measuring indicators of the outcomes. ${ }^{7}$ We now discuss each of the four elements of SBRs in turn.

\section{The Way the Private Sector is Organised Vis-à-Vis the Public Sector}

Good SBRs cannot be sustained in the long run without effective private sector participation. Weiss (1998) indicates that the more firms are involved in business associations the easier it is to coordinate policy between the government and business. The importance of business associations is further emphasised by Hisahiro (2005) who suggests they play a significant role in facilitating the formulation, implementation, and monitoring of economic policies and provision of feedback to the government. All encompassing business associations are more likely to engage in collective action by pressing for policies that bring about economic growth throughout the economy, rather than favour particular sectors at the expense of others (Olson, 1982). A representative umbrella organisation for all private sector associations is present in some countries. ${ }^{8}$ We measure the way the private sector is organised by giving a score of 0 for each country in a given year if it did not have a private sector umbrella organisation (PSUA) and giving a score of 1 if it did (see Table A1 for further details).

\section{The Way the Government is Organised Vis-à-Vis the Private Sector}

The government faces numerous decisions on how it may organise itself to interact with business. An important measure is the presence and effectiveness of an investment promotion agency (IPA) which could be seen as indicative of advocacy of private sector interests as a whole. ${ }^{9}$ We measure how the public sector is organised vis-à-vis the private sector by the presence and length of existence of an investment promotion agency (IPA) to promote business, a score of 0 for each country in a given year if it did not have an IPA and 1 if it did (see Table A1).

\section{The Practice and Institutionalisation of State-Business Relations}

Effective SBRs require the cooperation of the public and private sector, but cooperation and willingness alone may not be enough for dialogue to be useful and effective. To examine these qualities, we examine whether there is a mechanism of public-private dialogue. Without a mechanism, usually in the form of a forum, it is more difficult for the state and the private sector to be on agreeable terms in a transparent way, and to avoid harmful collusive behaviour. ${ }^{10}$ This mechanism can come in a number of different forms: it can be open to all and autonomous of government intervention as is the case with a formal existing body, or it can be an informal 'suggestive' body with no entrenched power. Forum statistics such as when it was founded and how often it meets will provide an idea of the forum's strength. We score 0 for each country in a given year if it did not have an institutionalised Public-Private Dialogue (PPD), 0.5 if it did but 
with frequency of one or fewer annual meetings, and 1 if it did with a frequency of two or more meetings (see Table A1).

\section{Mechanisms to Avoid Harmful Collusive Behaviour}

Competition laws are created for the benefit of business competition and promoting the creation of new business. Both the existence of such laws and the length of their existence will be used as initial indicators of a country's commitment to such competition policies, though it will also be important to consider whether the laws have been effective (for a discussion see Voight, 2009). We measure the presence of anti-collusive behaviour (COMP) by scoring 0 for each country in a given year if it did not have a competition policy in place, 0.5 if it did have a policy in place but there is evidence that it was not effective, and 1 if it did and it was effective (see Table A1). ${ }^{11}$

Each of the four elements can be measured over time. This leads to four, timevarying indicators per country. In order to obtain a composite measure, we take the average of the above indicators for the country in question for a given year (attaching the same weight to each indicator). Figure 1 plots the averages for four groups of countries, ranging from the fastest growing groups over 1970-2005 (group 1 ) to the slowest growing group (group 4). As expected country groups with higher SBR scores grow faster. ${ }^{12}$

\section{Empirical Specification, Data and Econometric Methodology}

In this section, we first discuss the specification to be used in the estimation of the determinants of economic growth. We then describe the data used in the regressions, followed by a brief exposition of the econometric methodology.

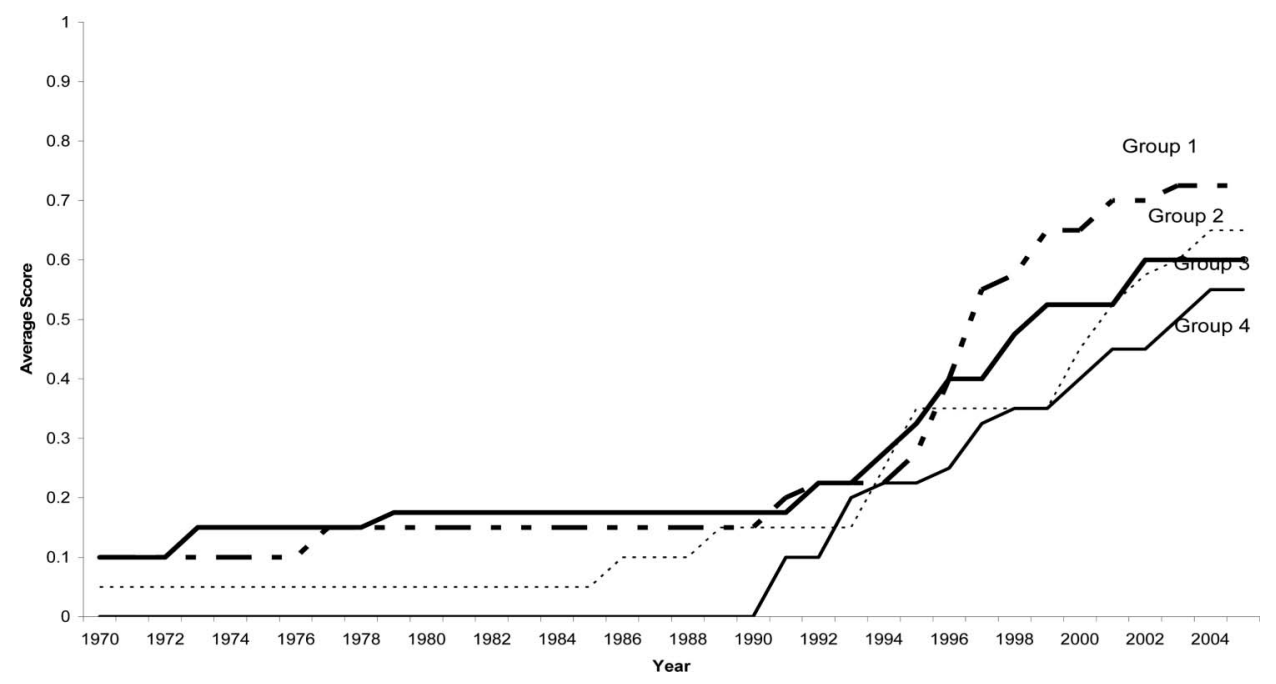

Figure 1. Higher SBR scores for groups of faster growing countries. Notes: Group $1=$ Botswana, Mauritius, Uganda, Mozambique, Mali; Group 2 = Tanzania, Ghana, Senegal, Kenya; Group $3=$ Benin, Ethiopia, South Africa, Nigeria, Rwanda; Group $4=$ Malawi, Zimbabwe, Madagascar, Zambia, Cote d'Ivoire. Groups based on GDP per capita growth rates over 1980-2004. 


\section{Empirical Specification}

Our objective is to examine the effect of our measure of effective state-business relationships (SBRs) independently of other factors that have been found to determine economic growth across countries and over time. We start with the formulation of a growth regression in panel data form, with SBR as an additional explanatory variable:

$$
Y_{i t}=a_{0}+a_{1} Y_{i t-1}+a_{2} X_{i t}+a_{3} S B R_{i t}+v_{i}+u_{t}+e_{i t}
$$

Where $i$ designates country, $t$ designates time, $Y$ is the logarithm of GDP per capita, and $X_{i t}$ is a vector of standard macro control variables. As is standard in the literature, we use Government Consumption (as a ratio of GDP), Inflation (per cent) and Openness to trade, measured by Exports plus Imports as a ratio of GDP, as our initial control variables (Barro, 1997). The error terms $v_{i}$ and $u_{t}$ capture the timeinvariant and country-invariant components of the error term, while $e_{i t}$ is the white noise component of the error term.

The presence of the lagged GDP term, $Y_{i t-1}$, is important for two reasons. Firstly, it captures path dependence in growth experiences as has been found to be the case in most historical accounts of economic growth (Rodrik, 2003). Secondly, it captures the conditional convergence hypothesis predicted by the neoclassical theory of economic growth - a negative and significant coefficient on the lagged GDP term indicates that countries relative to their steady-state output level are experiencing a slowdown in economic growth (Caselli et al., 1996). Given our discussion in Section III, we postulate that the coefficient on SBR, $a_{3}$, is positive and statistically significant. ${ }^{13}$

We would also like to examine whether effective state business relationships matter for economic growth independent of other measures of institutional quality that have been found to be important in the cross-country empirical literature on growth. This also allows us to ascertain whether our measure of effective state-business relationships is simply capturing other institutions that seem to matter for economic growth - respect for property rights or the quality of the bureaucracy, for example. Previous empirical studies of the role of institutions in growth measure institutional quality by the rule of law index (Knack and Keefer, 1995; Sachs and Warner, 1997), the risk of expropriation (Acemoglu et al., 2001), government repudiation of contracts (Knack and Keefer, 1995; Sachs and Warner, 1997), bureaucratic quality (Knack and Keefer, 1995; Sachs and Warner, 1997), incidence of corruption (Mauro, 1995), and constraints on the executive (Glaeser et al., 2004). To see whether SBR can explain economic growth independent of these other institutional variables, we augment equation (1) by these measures and test for the significance of SBR. ${ }^{14}$

Thus, our augmented regression is:

$$
\begin{aligned}
Y_{i t}= & a_{0}+a_{1} Y_{i t-1}+a_{2} X_{i t}+a_{3} S B R_{i t}+a_{4} L A W_{i t}+a_{5} B Q_{i t}+a_{6} C O R R_{i t} \\
& +a_{7} X C_{i t}+v_{i}+u_{t}+e_{i t}
\end{aligned}
$$

where $L A W$ measures the rule of law and reflects the degree to which citizens of a country are willing to accept the established institutions to make and implement laws and adjudicate disputes; $B Q$ is the bureaucratic quality index and measures autonomy 
from political pressure and strength and expertise to govern without drastic changes in policy or interruptions in government services; CORR is the corruption in government index and measures whether illegal payments are generally expected throughout government in the form of bribes connected with import and export licences, exchange controls, tax assessments, police protection, or loans; and $X C$ is a measure of extent of institutionalised constraints on the decision making powers of chief executives. For all these variables, higher values imply greater institutional quality (that is, higher values of $L A W, B Q, C O R R$ and $X C$ imply higher prevalence of the rule of law, better quality of the bureaucracy, lower corruption and greater constraints on the executive). Clearly, the coefficients $a_{4}, a_{5}, a_{6}$, and $a_{7}$ are expected to be positive and significant. Our interest is to determine whether $a_{3}$ remains positive and significant in the presence of the alternate measures of institutional quality.

\section{Data}

We use a panel of 19 SSA countries for the period 1970-2004 (see Table A1 for the list of countries, constrained by the availability of data on the SBR measure). Economic growth is measured by the year to year changes in GDP per capita, where the latter is in 1980 constant price local currency. ${ }^{15}$ Data on GDP per capita along with government consumption $(G C)$, inflation $(I N F L)$ and openness [exports + imports as a ratio of GDP] (OPEN) are obtained from the World Bank's World Development Indicators. Data on bureaucratic quality $(B Q)$, rule of law $(L A W)$, and corruption $(C O R R)$ are obtained from the International Country Risk Guide published by Political Risk Services (PRS). These measures were originally constructed by the Centre for Institutional Reform and the Informal Sector (IRIS) (see Knack and Keefer, 1995, for further details). The variables are only available for the period 1987-2004. Data on executive constraints (XC) are obtained from the online database of the Polity IV project hosted by the Centre for International Development and Conflict Management in the University of Maryland. This variable is available for the entire period 1970-2004.

Summary statistics of the variables to be used in the regressions are presented in Table 1. There is wide variation in our sample in our dependent variable - income per capita - and some of the macro control variables - inflation and openness - and the measure of executive constraints, and less so in our measure of state-business relationships and in measures of the rule of law, bureaucratic quality and corruption. We also compute correlation coefficients between the variables of interest in Table 2 to assess the strength of association between each pair of variables that we will be using later in the econometric analysis. The correlation coefficients are quite low in most cases, suggesting that we should not expect multicollinearity between the SBR measure and the macroeconomic variables, and between the SBR measure and the other measures of institutional quality. The latter is an interesting finding as it suggests standard measures of institutions may capture some aspects of the institutional quality but the SBR measure captures additional information. ${ }^{16}$

\section{Econometric Methodology}

Our panel data have a long time dimension $(\mathrm{T}=34)$ and a relatively short crosssectional dimension $(\mathrm{N}=19)$. In this case, the Least Squares Dummy Variable 
Table 1. Summary statistics

\begin{tabular}{lcccc}
\hline Variables & Mean & Maximum & Minimum & Standard Deviation \\
\hline Log Y & 10.12 & 14.64 & 5.29 & 2.37 \\
SBR & 0.225 & 1.000 & 0.000 & 0.274 \\
INF & 17.46 & 350.18 & -14.17 & 4.31 \\
GC & 14.65 & 34.33 & 5.86 & 26.27 \\
OPEN & 58.68 & 164.24 & 6.32 & 16.24 \\
XC & 0.35 & 7.00 & -88.00 & 1.16 \\
LAW & 3.00 & 5.00 & 0.00 & 1.33 \\
BQ & 2.28 & 6.00 & 0.00 & 1.01 \\
CORR & 2.91 & 6.00 & 0.00 & \\
\hline
\end{tabular}

Notes: $\log \mathrm{Y}=$ Logarithm of Real GDP per capita in local currency, SBR $=$ State Business Relationship Score, INF = Inflation Rate (per cent), GC= Government Consumption/GDP, OPEN $=$ Exports + Imports/GDP, XC = Executive Constraints, LAW $=$ Rule of Law, $\mathrm{BQ}=$ Bureaucratic Quality, CORR = Corruption. See Text in Section IV for sources of data.

Table 2. Correlation coefficients

\begin{tabular}{lrrrcccccc}
\hline Variables & Log Y & SBR & INF & GC & OPEN & XC & LAW & BQ & CORR \\
\hline Log Y & 1.00 & \multicolumn{1}{c}{ I } & - & - & - & - & - & - & - \\
SBR & -0.01 & 1.00 & - & - & - & - & - & - & - \\
INF & 0.01 & -0.09 & 1.00 & - & - & - & - & - & - \\
GC & -0.22 & 0.21 & -0.03 & 1.00 & - & - & - & - & - \\
OPEN & -0.04 & 0.25 & -0.03 & 0.38 & 1.00 & - & - & - & - \\
XC & 0.09 & 0.09 & 0.03 & 0.16 & 0.15 & 1.00 & - & - & - \\
LAW & 0.01 & 0.20 & -0.31 & 0.09 & 0.24 & 0.14 & 1.00 & - & - \\
BQ & -0.04 & -0.02 & -0.02 & 0.30 & 0.09 & 0.08 & 0.01 & 1.00 & - \\
CORR & 0.13 & -0.07 & -0.17 & 0.07 & -0.02 & 0.07 & 0.19 & 0.54 & 1.00 \\
\hline
\end{tabular}

Notes: Log Y = Logarithm of Real GDP per capita in local currency, SBR $=$ State Business Relationship Score, INF = Inflation Rate (per cent), GC= Government Consumption/GDP, OPEN $=$ Exports + Imports/GDP, XC = Executive Constraints, LAW $=$ Rule of Law, $\mathrm{BQ}=$ Bureaucratic Quality, CORR = Corruption. See Text in Section IV for sources of data.

(LSDV) estimator is the preferred method, in comparison with the Generalised Method of Moments (GMM) estimator which is more appropriate when the crosssectional dimension is larger than the time dimension. As Judson and Owen (1999) have shown, the LSDV estimator performs just as well or better than alternatives when the time dimension exceeds 30, as it does in our case. We use the LSDV estimator as our preferred panel data estimator, though we also experiment with instrumental variable and GMM estimators to check the robustness of our results. The advantage of the GMM estimator, in particular, is that it eliminates any endogeneity that may be due to the correlation of the country specific effects and the independent variables.

\section{Results}

Table 3 presents the results for the basic and augmented specifications. In Col. (1), we present the results of the basic specification, with the SBR measure and the macro 


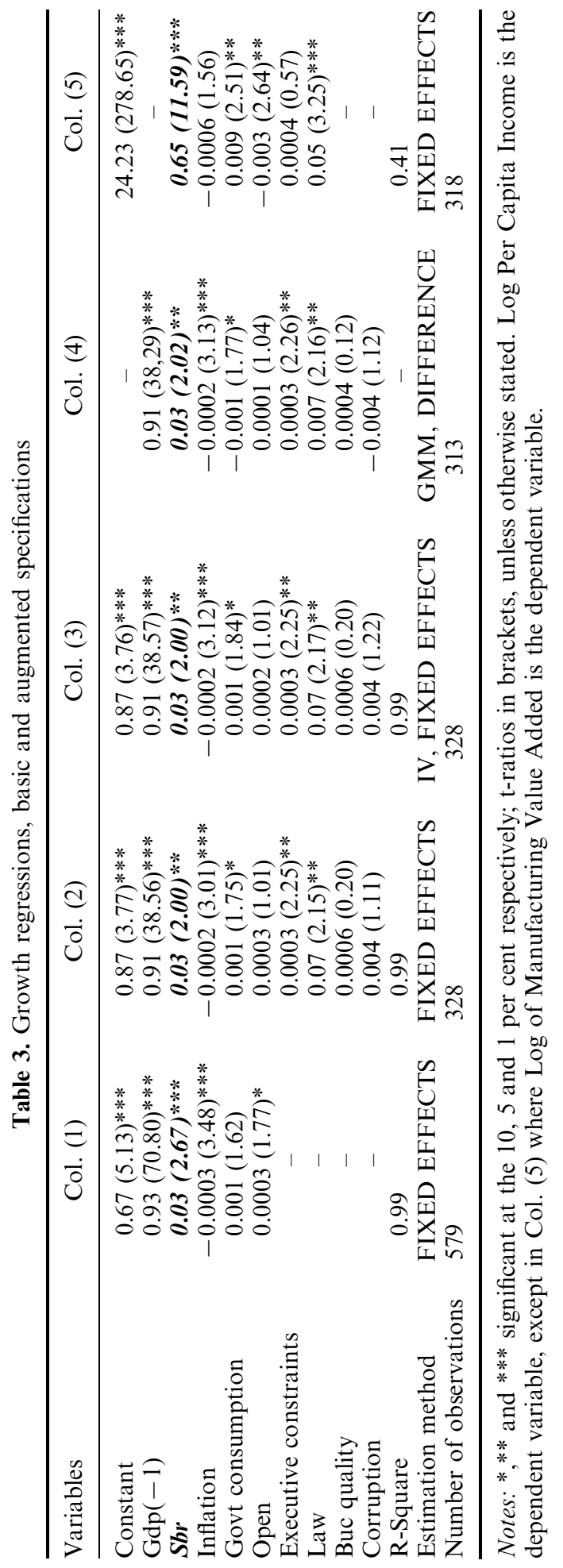


controls included, but not the other institutional quality variables. In Col. (2), we include the other measures of institutional quality. In Col. (3), we use the instrumental variable (IV) fixed effects estimator to allow for possible endogeneity of the SBR measure and the openness measure. We use one period lagged values of the SBR measure and openness as instruments. In Col (4), we estimate the augmented specification of equation (2) using the GMM estimator. ${ }^{17}$ Finally, in Col. (5), we estimate the growth regression substituting manufacturing value added for GDP per capita as the dependent variable, as a direct test of whether SBRs matter for economic performance. ${ }^{18}$ We would expect that effective SBRs would matter more for the performance of the manufacturing sector, given that the presence of business associations, investment promotion agencies and the enactment of competition laws would pertain more to the manufacturing sector than the agricultural sector.

Among the macro controls, only the coefficient on inflation is statistically significant and of the expected sign (negative) in all the four estimates. The coefficient on government consumption is negative and statistically significant only for the final estimate. The coefficient on openness is positive and significant (at the 10 per cent level) only for the basic specification. Among the conventional measures of institutional quality, the coefficients on executive constraints and the rule of law are positive and significant in all the equations. However, the coefficients on bureaucratic quality or corruption are not statistically significant in any of them.

The striking result is that the coefficient on SBR is positive and significant at the 5 per cent level or better for all five estimates presented in Cols (1) to (5). The value of the coefficient on the SBR variable remains remarkably consistent at 0.03 for all the estimates where GDP per capita is the dependent variable, whether in the basic or augmented specification or using LSDV, IV or GMM methods. ${ }^{19}$ Thus, the magnitude of the impact of SBR on per capita income is robust to different specifications and estimation procedures of the growth equation. The significance of the SBR variable remains even when the more commonly used measures of institutional quality are included, such as the degree of executive constraints, the rule of law, corruption and the quality of the bureaucracy. Our results suggest that our measure of SBRs captures a different dimension of institutional quality from those ordinarily studied in the literature on institutions and growth. In Col. (5), when we estimate the effect of SBR on manufacturing value added instead of GDP per capita, we find as expected that the coefficient on SBR is positive and highly significant at the one per cent level in this estimate. ${ }^{20}$ Thus, there is strong support for the proposition that effective state-business relationships matter for economic growth in sub-Saharan Africa, independent of other measures of institutional quality and macroeconomic factors. $^{21}$

One limitation of using annual data is that short-run and cyclical factors may dominate over the long-trend factors that determine economic growth (Islam, 1995). We also estimated growth regressions using three year period averages of our annual data to see if our results are robust to a lower frequency of the data (results reported in the Online Appendix). The use of three-year averages also allow us to bring in time-invariant cross-sectional variables that have been commonly used in the empirical growth literature as the time dimension is now lower than the crosssectional dimension ( $\mathrm{T}=12$ as compared to $\mathrm{N}=19$ ). 
We used both Ordinary Least Squares (OLS) and Two Stage Least Squares (TSLS) estimators, the latter to allow for possible endogeneity of the institutional measures that were included along with the SBR measure. We controlled for timeinvariant factors that may affect economic growth such as geographical factors (being landlocked and natural resource dependence). The description of the institutional measures and other controls used are contained in the Online Appendix and the results presented in Table $\mathrm{O} 2$. We found that the coefficient on SBR is positive and significant at the one percent level of significance in the OLS estimates, and at the 5 per cent level in the TSLS estimates. As observed in the case when we used annual data, there is a remarkable robustness to our finding that an increase in effective state-business relations as captured in our SBR measure has a strong positive effect on economic growth even when we use period-averaged data.

\section{Conclusions}

The importance of benign collaboration between the state and business has been recognised by political scientists and political economists as being central in the understanding of economic growth in developing countries. However, there has been little attempt in this literature to 'measure' effective state-business relations and to quantify the effect of good state-business relations on economic growth in subSaharan Africa, with much of the evidence reliant on country case studies and qualitative methods that cannot be generalised to the rest of sub-Saharan Africa.

In this paper, we address an over-looked determinant of economic growth in subSaharan Africa - the effectiveness of the relationship between the state and the business sector. We propose a quantitative measure that can capture the main dimensions of effective state-business relationships (reciprocity, credibility, transparency): i) the way in which the private sector is organised vis-à-vis the public sector; ii) the way in which the public sector is organised vis-à-vis the private sector; iii) the practice and institutionalisation of SBRs; and iv) the avoidance of harmful collusive behaviour. We find that this measure shows an unambiguous improvement in state-business relationships in sub-Saharan Africa over 1970-2004, though there are significant differences in the rate of improvement across countries.

Using this measure, we estimate standard growth regressions in panel form for 19 sub-Saharan African countries with other controls for the macroeconomic environment, along with the more conventionally used measures of institutional quality in the empirical literature. Our results show that effective state-business relationships contribute significantly to economic growth in sub-Saharan Africa countries which have shown improvements in state-business relationships have witnessed higher economic growth, controlling for other determinants of economic growth. Our findings are robust to the use of alternative estimators and to alternative specifications.

Our results suggest that improvements in formalised institutional relations between the state and the private sector increase economic growth in the African context. These institutional relations could be the creation of umbrella business associations, the setting up of Investment Promotion Agencies, formalised publicprivate dialogues or the implementation of competition law. Umbrella business associations can help resolve collective action problems for the private sector and 
allow them to push for growth enhancing policies. The creation of Investment Promotion Agencies signals the intention of the government to take the private sector and investment activity seriously. Formalised public-private sector dialogue processes allow for transparency in policy formulation and efficient dissemination of information from both the public and the private sectors. Effective competition laws prevent rent-seeking and collusive behaviour on the part of bureaucrats and capitalists. Our research shows that the creation and sustenance of effective statebusiness relations along these lines may have a stronger impact on economic growth in sub-Saharan Africa than the conventional measures of governance reform such as improvements in the rule of law and stronger anti-corruption measures that have been stressed in the literature and in the policy debate.

While we have suggested there are certain key principles behind effective SBRs, this does not mean that each country should follow one institutional blue print. Indeed, this study does not indicate whether certain types of SBRs or business associations work better than others (as explained in Doner and Schneider, 2000 for non-African developing countries) and this is likely to be context specific. It does not identify which economic function is most relevant in which country, for example reduction in policy uncertainty or lobbying government (as suggested in the microeconometric study for Zambia by Qureshi and Te Velde, 2007). While this study does show that state-business relations can be good for enhancing growth, which by itself is an important policy finding given the historically sceptical view toward the private sector in Africa as being solely rent-seeking, there is much left to research at the country level. Perhaps most importantly, the analysis shows that our SBR measure does have empirical meaning, so the nature of state-business relations in Africa is worthy of further study.

\section{Notes}

1. Fajnzylber et al. (2009) address aspects of the impact of forms of government support on Mexican micro firms, using various techniques to identify treatment effects of credit, training and tax payments (as a measure of formality, hence a proxy for potential access to public services) on firm profits, growth and survival likelihood. They find that although access to these forms of support does not appear to significantly influence profits, 'formality' and access to credit improve the likelihood of survival. They argue that facilitating access to credit and business development services and promoting formalisation (which is similar to state-business relations) are all likely to increase firm growth. In this way, there is some evidence that SBRs, at the micro level, can support private sector development, hence contribute to growth. In a similar vein, Hansen et al. (2009) explore the effects of direct government assistance during start-up and other forms of interaction with the state (hence relating to aspects of SBRs) on the long-run performance of small and medium-sized manufacturing enterprises in Vietnam. They find strong effects on firm dynamics (survival and growth) from interaction with state institutions - providing further micro evidence that SBRs matter for firm performance.

2. There is also a wider literature that discusses the possibility of an East Asian-type developmental state in the sub-Saharan African context; Mkandawire (2001) argues that the institutional relations that governed state-business interactions in East Asia are also possible in Africa.

3. 'Institutions are the rules of the game in a society or, more formally, are the humanly devised constraints that shape human interaction' (North, 1990, p.1). State-business relations can be seen as a set of interactions between states and the business sector whether through formal channels such as official meetings of bureaucrats with business associations, or through more informal channels such as phone conversations and dinner parties.

4. See Te Velde (2006) for country level descriptions of the indices. 
5. Bräutigam et al. (2002), which examines the nature of 'growth coalitions' involving business interest groups and the government in Mauritius, Zambia and Zimbabwe, is an exception.

6. For example, the restrictiveness of trade policy is best measured using tariff or quotas rather than import penetration ratios, as the latter is an outcome of trade policy changes rather than the measure of these changes.

7. This is an important distinction. The creation of an Export Processing Zone, for example, is an outcome of an effective SBR, rather than a measure of an effective SBR. By making this distinction, we avoid to a large extent the endogeneity problems that are endemic to outcome based measures of institutions. See Glaeser et al. (2004) for a critique of outcome-based measures of institutions that are used in the literature.

8. Case study evidence also supports the argument that well organised business associations can be important in pushing for growth-oriented policies. For example, the Ivorian Chamber of Industry played an important role in arguing for policies supporting export-oriented manufacturing (Rapley, 1994). The Private Sector Foundation in Uganda is mandated to do policy research and advocacy for the private sector and has achieved improvements in the investment climate such as lower tariffs on key imports, upgrading of infrastructure and streamlining of public procurement (Badagawa, 2008).

9. An example of a successful IPA in the African context is the Rwandan Investment Promoting Agency (RIPA), formed in 1998, but which changed its name six years later to Rwanda Investment and Export Promoting Agency (RIEPA). This semi-autonomous agency has made great strides in working with the private sector and gaining its input on reform measures (Te Velde 2006).

10. An example of a successful institutionalised public-private dialogue process is the Joint Economic Council (JEC) in Mauritius: 'over the years, the JEC has become institutionalised as a strong and legitimate 'peak' association for businesses in Mauritius, an encompassing group that represents all the major sectors and works out broadly agreeable positions on economic policy' (Bräutigam et al., 2002: 526). The JEC discusses with the Minister of Finance a draft budget and presents proposals which to a varying degree are taken over in the final budget.

11. The mere passage of competition law does not imply that it will be implemented. In 1995, Senegal passed the Decree on Price, Competition and Economic Contentious to prevent the commerce industry from colluding. However, more recent anti-corruption laws while accepted have been accused of being 'watered-down' by Parliament (Te Velde, 2006).

12. Two caveats should be pointed out with our measure. Firstly, our measure is simply capturing the formal aspects of state-business relations, and not the informal aspects. The latter are to a large extent 'not observable', and therefore cannot be quantified. Secondly, our measure may not be easily generalised outside of sub-Saharan Africa. In the latter context, there was no long-standing history of umbrella business associations such as existed in India. There have been only recently attempts by the governments of many African countries to actively solicit private investment via the creation of Investment Promotion Agencies. These features of state-business relations in sub-Saharan Africa allow us variation in the time dimension, and also in the cross-section dimension, which may not hold true for other regions such as East and South Asia.

13. We assume that the coefficient on SBR is the same over time. However, Figure 1 seems to indicate that the progress in state business relations has varied greatly across countries. When we experimented with changes in the coefficient on SBR over time, interacting the SBR variable with period dummies, these interaction dummies were not statistically significant, suggesting that the assumption of the effect of SBR being constant over time is supported by the data.

14. Unfortunately, data on expropriation risk and government repudiation of contracts are only available for 1987-1994 so we do not use these variables in the augmented regressions.

15. We do not use constant PPP prices as there are insufficient data for all countries in the sample period. However, for a smaller set of countries for a shorter period, we used GDP in constant PPP prices with no change in the results.

16. We also estimated correlations of our measure and the World Bank's Kaufmann governance indicators, based on perceptions of government effectiveness, rule of law, and so on, on a yearly basis from 1996 to 2004 (see Te Velde, 2006). We find that there is no significant correlation with control of corruption and political stability, but a significant correlation of our measure with the indicators Voice and Accountability, Government Effectiveness and Regulatory Quality in most of the years and a significant correlation with rule of law for two years. Hence, there is a reasonable correlation across countries between SBR and perceptions of governance variables relevant for private sector 
development. We also compare the SBR variable with the various Investment Climate Indicators contained in the World Bank's Doing Business reports. These indicators describe the difficulties faced by normal business operations, such as the number of procedures it takes to obtain licences, export goods and services. We found that higher scores on the SBR measure tend to lead to a more streamlined administration, such as fewer regulations and time wasted when trading (Te Velde, 2006).

17. The GMM estimator is appropriately specified if the over-identifying restrictions are not rejected, the test for first order serial correlation cannot reject the null of no correlation, but the test for second order serial correlation does reject the null of no correlation by any standard levels of significance (Arellano and Bond, 1991). We found that the Sargan test did not reject the over-identification restrictions, the absence of first order serial correlation was rejected and the absence of second order serial correlation was not rejected. Hence, the GMM estimates presented in Col (4) of Table 3 was properly specified.

18. We obtain data for manufacturing value added from the World Development Indicators.

19. We also used the system GMM estimator (Arellano and Bover, 1995) instead of the difference GMM estimator with no change in the results.

20. We omit corruption and bureaucratic quality in this regression as they have been found insignificant in previous estimates.

21. We also estimated the growth regression with each of the four components of the SBR measure entered in the regression one by one. These results are presented in Table O1 of the Online Appendix. We find that among the four components, the measures for the existence of a private sector umbrella organisation (PSUA), the presence of an Investment Promotion Agency (IPA), and the presence of formalised publicprivate dialogue are all positive and statistically significant, while the measure for the implementation of competition policy is not. This suggests that among the four components of SBRs, the ones that matter most for growth are the existence of a private sector umbrella organisation, the presence of an Investment Promotion Agency, and the presence of formalised public-private dialogue.

\section{References}

Acemoglu, D., Johnson, S. and Robinson, J. (2001) The colonial origins of comparative development. American Economic Review, 91(5), pp. 1369-1401.

Amsden, A. (1989) Asia's Next Giant: South Korea and Late Industrialisation (New York: Oxford University Press).

Artadi, E. and Sala-i-Martin, X. (2003) The economic tragedy of the XXth century: growth in Africa. NBER Working Paper No. 9865, Cambridge, MA.

Arellano, M. and Bond, S. (1991) Some tests of specification for panel data: Monte Carlo evidence and an application to employment equation. Review of Economic Studies, 58(2), pp. 277-297.

Arellano, M. and Bover, O. (1995), Another look at the instrumental variable estimation of error components models. Journal of Econometrics, 68(1), pp. 29-52.

Badagawa, G. (2008) Public-private dialogue. the PSFU experience. Presentation at a PPD workshop in Senegal, 3 April 2008. Available at: http://www.publicprivatedialogue.org/workshop\%202008/ PSFU\%20PPD \%20process\%20-\%20Dakar.ppt

Barro, R. (1997) Determinants of Economic Growth (Cambridge, MA: The MIT Press).

Bräutigam, D., Rakner, L. and Taylor, S. (2002) Business associations and growth coalitions in subSaharan Africa. Journal of Modern African Studies, 40(4), pp. 519-547.

Casseli, F., Esquivel, G. and Lefort, F. (1996) Reopening the convergence debate: a new look at crosscountry growth empirics. Journal of Economic Growth, 1(3), pp. 363-389.

Collier, P. and Gunning, J.W. (1999) Explaining African performance. Journal of Economic Literature, 37(1), pp. 64-111.

Dixit, A. and. Pindyck, R. (1994) Investment under Uncertainty (Princeton: Princeton University Press).

Doner, R.F. and Schneider, M.R. (2000) Business associations and economic development: why some associations contribute more than others. Business and Politics, 2(3), pp. 261-288.

Easterly, W. and Levine, R. (1997) Africa's growth tragedies: policies and ethnic divisions. Quarterly Journal of Economics, 112(4), pp. 1203-1250.

Evans, P. (1995) Embedded Autonomy: States and Industrial Transformation (Princeton: Princeton University Press). 
Fajnzylber, P., Maloney, W.F. and Montes-Rojas, G.V. (2009) Releasing constraints to growth or pushing on a string? Policies and performance of Mexican micro-firms. Journal of Development Studies, 45(7), pp. 1027-1047.

Glaeser, E., La Porta, R. and Lopez-de-Silanes, F. (2004) Do institutions cause growth? Journal of Economic Growth, 9(3), pp. 271-303.

Gyimah-Brempong, K. and Corley, M. (2005) Civil wars and economic growth in sub-Saharan Africa. Journal of African Economies, 14(2), pp. 270-311.

Hall, R. and Jones, C.I. (1999) Why do some countries produce so much more output per worker than others? Quarterly Journal of Economics, 114(1), pp. 83-116.

Hansen, H., Rand, J. and Tarp, F. (2009) Enterprise growth and survival in Vietnam: does government support matter? Journal of Development Studies, 45(7), pp. 1048-1069.

Harriss, John (2006) Institutions and state-business relations. Improving Institutions for Pro-Poor Growth (IPPG) Briefing Note 2, London. Available at http://www.ippg.org.uk/publications.html

Herbst, J. (1993) The Politics of Reforms in Ghana, 1982-1991 (Berkeley, CA: University of California Press).

Hisahiro, K. (2005) Comparative analysis of governance: relationship between bureaucracy and policy coordination capacity with particular reference to Bangladesh. Institute for International Cooperation. Available at: http://www.jica.go.jp/kokusouken/enterprise/chosakenkyu/kyakuin/200509_gov.html

Hyden, G., Court, J. and Maese, K. (2004), Making Sense of Governance: Empirical Evidence from Sixteen Developing Countries (Boulder, CO: Lynne Rienner).

Islam, N. (1995) Growth empirics: a panel data approach. Quarterly Journal of Economics, 110(4), pp. $1127-1170$.

Johnson, C. (1987) Political institutions and economic performance: the government-business relation in Japan, South Korea and Taiwan, in: F. Deyo (ed.) The Political Economy of the New Asian Industrialism (Ithaca: Cornell University Press), pp. 136-164.

Judson, R.A. and Owen, A.L. (1999) Estimating dynamic panel data models: a guide for macroeconomists. Economic Letters, 65(1), pp. 9-15.

Kaufmann, D., Kraay, A. and Mastruzzi, M. (2005) Governance matters IV: governance indicators for 1996-2004. Available at: http://www.worldbank.org/wbi/governance/data.html\#dataset

Knack, S. and Keefer, P. (1995) Institutions and economic performance: cross-country tests using alternative measures. Economics and Politics, 7(3), pp. 207-227.

Mauro, P. (1995) Corruption and growth. The Quarterly Journal of Economics, 60(3), pp. 681-713.

Maxfield, S. and Schneider, B.R. (1997) Business and the State in Developing Countries (Ithaca: Cornell University Press).

Mkandawire, T. (2001) Thinking about developmental states in Africa. Cambridge Journal of Economics, 25(3), pp. 289-313.

North, D.C. (1990) Institutions, Institutional Change and Economic Performance (Cambridge: Cambridge University Press).

Olson, M. (1982) The Rise and Decline of Nations (New Haven: Yale University Press).

Qureshi, M. and Te Velde, D.W. (2007) State-business relations and firm performance in Zambia. IPPG Discussion Paper 5, London. Available at: http://www.ippg.org.uk/publications.html

Rapley, J. (1994) The Ivorian Bourgeoisie, in: J.B. Berman and C. Leys (eds) African Capitalists in African Development (Boulder, CO: Lynne Rienner), pp 39-68.

Robinson, J. and. Parsons, Q.N. (2006) State formation and governance in Botswana. Journal of African Economies, 15(Supplement), pp. 100-140.

Rodrik, D. (2003) In Search of Prosperity: Analytic Narratives on Economic Growth (Princeton: Princeton University Press).

Rodrik, D., Subramanian, A. and Trebbi, F. (2004) Institutions rule: the primacy of institutions over geography and integration in economic development. Journal of Economic Growth, 9(2), pp. 31-165.

Sachs, J. and Warner, A.M. (1997) Sources of slow growth in African economies. Journal of African Economies, 6(3), pp. 335-376.

Te Velde, D.W. (2006), Measuring state business relations in sub-Saharan Africa. IPPG Discussion Paper No. 4, London. Available at www.ippg.org.uk/publications.html

Voight, S. (2009) The effects of competition policy on development - cross-country evidence using four new indicators. Journal of Development Studies, 45(8), pp. 1225-1248.

Weiss, L. (1998). The Myth of the Powerless State (Ithaca, NY: Cornell University Press). 
State Business Relations in Africa 1283

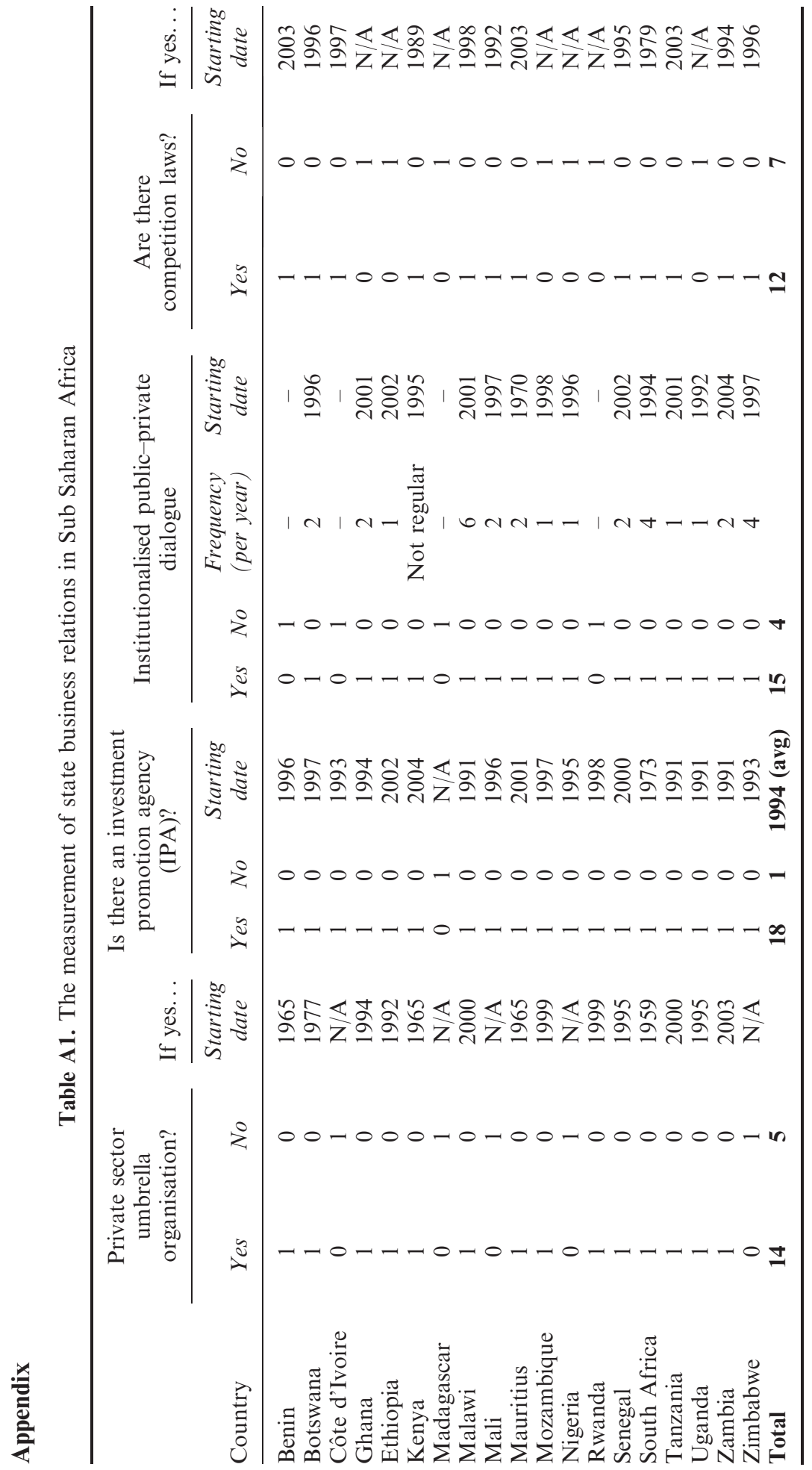

